\title{
PARTNERSHIP, A NEW APPROACH FOR THE URBAN MANAGEMENT OF IRAN: CASE STUDY - MANAGEMENT OF MASHHAD RELIGIOUS METROPOLIS
}

\author{
A.A. PILEHVAR \\ Department of Urban Planning, Bojnord University, Iran.
}

\begin{abstract}
In the last one hundred years, Iran has been facing too many difficulties with respect to its urban management as a result of changes in the government system. The governor or magistrate and the king's agent were in charge of the affairs in the city. The year 1907 is considered as an important transition point in Iran. In this year, some rules were introduced concerning management of the cities and establishment of the municipality. The rules of the municipality were amended four times until the victory of the Islamic Revolution of Iran in 1978 , and the mayor was elected not by the people but by the government representative to manage the affairs of the city. The Islamic Revolution in 1978 brought with it understanding of cooperation, especially in urban management, but it was not until 1998 that the right circumstances arose for citizens to take part and share in managing the affairs of the city. The election for the Islamic Council of the city was held in 1998, which was a new approach in cooperation and the urban management of Iran. This article discusses the process of managing the affairs of cities during the imperial and Islamic periods, in the last one hundred years, and analyzes the new model of council management in the Islamic system, touching upon the management of the religious metropolis in Mashhad (which is the second largest religious metropolis in the world and is visited by over 12 million pilgrims annually) as a model. The author will also deal with the method of improvement in urban management and council management and present some new recommendations in managing the metropolis in the 21 st century.
\end{abstract}

Keywords: council, Iran, Islamic revolution, king, Mashhad metropolis, municipality, partnership, urban management.

\section{INTRODUCTION}

The current trend of urbanization shows that the percentage of city dwellers in the world will increase from $47 \%$ in the year 2000 to $60 \%$ by the year 2030 [1]. On the other hand, the emergence of problematic metropolises and megacities in the world necessitates the question of revising their management in the 21st century. Moreover, the challenges facing the world, especially the developing countries, which reflect the instability of world development, especially in metropolises, have made civil studies and presenting new strategies for managing cities all the more important.

In recent decades, the rapid growth of urbanization in developing countries, including Iran, has added to instability and urban problems, while these countries have been experiencing modernism and development patterns that are not compatible with their environmental and structural conditions.

In the 20th century, Iran experienced three different political systems (constitutional government, monarchy, and republic). As a result, the country faced many challenges in the management of the cities. Partnership as a principle of city management has only been used in the last 3 years. On the other hand, a study of urban management and its historical trend requires a structural-functional analysis of the three political systems. This will make it possible to present a comparative analysis of urban management before and after the 1978 revolution and describe the new management system based on partnership. This article thus describes urban management in the last hundred years using the case study of the Mashhad religious metropolis and presents suggestions for the improvement of the world city management paradigm, especially metropolises, in the new millennium. 


\section{THE NECESSITY OF PARTNERSHIP AND COUNCILS FOR CITY ADMINISTRATION}

Cities, particularly metropolises, that undergo constant changes and show an unstable trend need to be managed using an approach based on partnership. This approach is a social process, taking place freely and consciously in the form of making decisions and taking part in planning affairs [2]. And it leads to self-governing and the exercise of lawful power in administrating affairs [3]. It is, in other words, a collective activity, a new approach in boosting the goals of development (including civil development), relying on citizens. In this approach, all people, groups, and organizations participate in economic, social, and cultural activities to achieve public goals in a shared space, namely the city [4].

Since the aim of every project in civil development is to reinforce political, social, and cultural aspects of civil life [5], it is necessary to focus on the basic fact in civil development, i.e. a general partnership of all components of a civil society (citizens, groups, and organizations), because civil partnership is the key to the success of projects and is considered as a criterion for the evaluation of the performance of the management in a city and its constituents (the council and the citizens) [6]. At the same time, participation in the management of a city can result in the promotion of trustfulness and spirit of cooperation among citizens and civil managers, and solving the problems of the city with the help of citizens. It can also affect the performance of civil management [7]. Global experience shows that after the 1980s, there has been an increasing emphasis on this approach [7]; partnership and council management in running the affairs of a city has been the result of cooperation in solving the problems of a city. The following factors explain the importance of partnership in civil management:

1. Partnership is a valuable learning process which prepares citizens appropriately to apprehend life's problems.

2. Partnership can make a project effective through adaptation with the real needs of the public and public demands [8].

3. Partnership can increase the efficiency of a project by motivating citizens to invest in them.

4. Partnership causes solidarity among the people of a nation.

5. Partnership can reinforce the spirit of citizenship [9].

The above factors are of high value and can motivate the development of the council system and indicate the importance of the partnership approach in civil management realized in council management.

The use of a partnership approach can lead to such results as the exercise of a self-governing system by tuning local organizations to local governments, reforming the managerial systems and organizational structure, and promoting trustfulness and spirit of cooperation among citizens and civil managers, as well as interest in participation in non-governmental organizations, all of which have different impacts on the process of council management (Fig. 1).

\section{A MODERN APPROACH TO CIVIL MANAGEMENT IN THE CONSTITUTIONAL REVOLUTION (1907)}

Before the constitutional revolution, the government in Iran was in the form of a dictatorial monarchy. (The constitutional revolution was a revolution against dictatorship that took place in 1907, as a result of which the foundations of democracy were laid with the establishment of the National Consultative Assembly, ratification of the constitution, the law of municipalities, etc. Thus the 


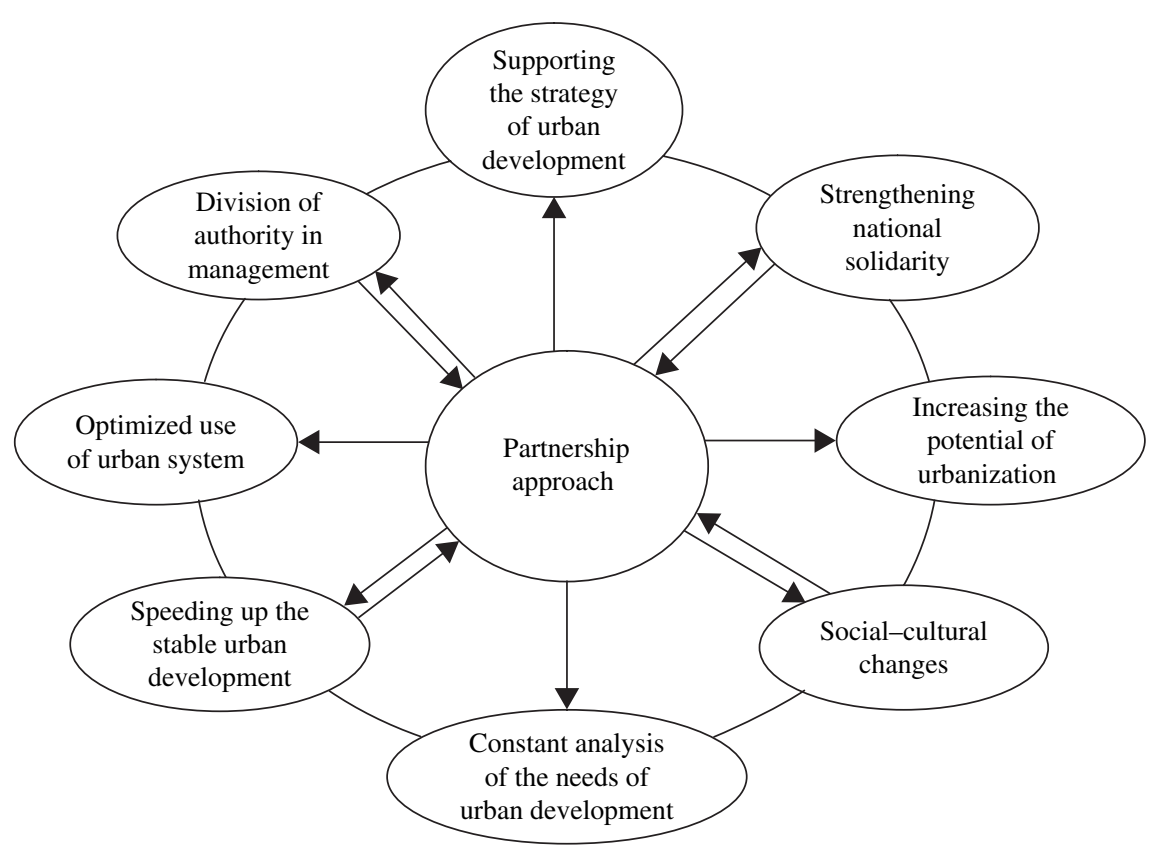

Figure 1: Partnership and change in urban management.

Shah lost part of his power.) In that governmental system, people had no say in running the local or central affairs [10]. Cities were no exceptions and the agent of the Shah and the governor of the city ruled each city. The constitutional revolution was a protest against the Qajar dictatorship and is considered as the starting point of reforms and a period of transition to an age of renovation [11]. In the course of this revolution, city and provincial councils were formed, the constitution was written, and attention was paid to the participation of the people in making policies and decisions of the government [12]. One of the positive outcomes of this revolution was the constitutional law concerning provincial and city councils. According to the law of provincial and city councils, there was a center in each province and in each city, and the duties of these centers were to control the administration of law and special aspects like security and construction [11]. Although the establishment of these councils as the first steps toward democracy in Iran was a positive act in the late Qajar period, there were serious obstacles in the way of implementation of such laws in practice. However, they never materialized because of intense political and social conditions, with the central government controlling everything [13]. Another result of the constitutional revolution was the ratification of the law of municipalities. Based on this law, each city would have a municipality and it was the city council's duty to run the affairs of the city (Fig. 2).

During the constitutional period, the urban population was less than $20 \%$, and the situation was not ripe for independent urban management. Illiteracy of most city dwellers, influence of local rich people, and lack of experience of government officials are the factors that contributed to the failure of the goals of the constitutional government and the laws passed by the parliament. Centralism thus proved a main obstacle in the way of people partnership. The same situation was present in the Pahlavi 


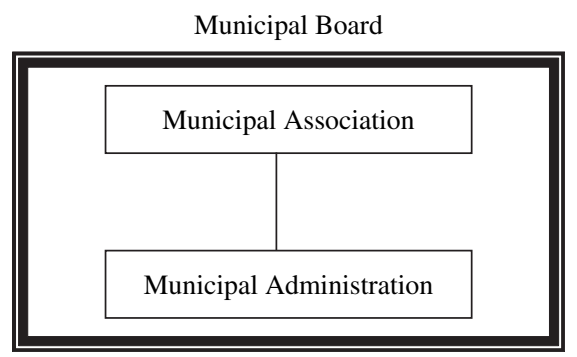

Figure 2: The structure of the first modern Iranian urban management system.

period 15 years later, a dictatorial regime with exclusive rights of ownership and the centralization of economic, administrative, and military power.

\section{THE PAHLAVI REGIME AND CENTRALIZED URBAN MANAGEMENT}

The coup d'etat of the year 1920 brought to an end the constitutional government, which lasted only 15 years. The new Pahlavi regime started its structural-functional changes with the ideas of modernism and renovation within the context of capitalism. As far as urbanization and urban management were concerned, they initially made laws for the destruction of the walls surrounding the city, following the western example of urbanization in their urban development projects and carried out the projects in a centralized manner. In 1930, the law of municipalities was cancelled and a new law was ratified according to which the municipalities gained legal independence and the ministry of the interior became responsible for planning of the cities and controlling their development. An increase in the urban population and the number of cities made the government revise the law of municipalities. In 1949, the parliament passed a new law concerning the establishment of municipalities and city councils. Based on this law, municipalities had no independence and full authority, and people had no right to intervene in the local affairs [14]. The gap between the government and the people was responsible for the failure of plans and programs that were not people-oriented. Urban management faced even more challenges as a result of economic and political changes.

In 1955, the law of municipalities was revised for the fourth time. In this revision, city councils gained less power and authority and the ministry of the interior became responsible for the appointment of mayors. Thus in the urban development process, the distribution of power and the partnership of the citizens had no meaning, and the ratification of the law of city councils did not mean the transfer of power, rather it was a political gesture to satisfy the people.

With the dominance of dictatorship over democracy, disregard for public needs, dependence on foreign countries, spread of bureaucracy, and injustice in the society, the council system was doomed from the beginning (Fig. 3).

The start of the industrialization process in Iran in the 1960s [15] was a heavy blow to the production economy, and with the production relations suffering, the number of immigrants to the cities increased [16].

The result was a wild expansion of cities, a breakdown of the class hierarchy in the cities, development of small cities around the big cities, and an increase in social and political tensions on the national scale in general and on the urban scale in particular [17]. The accumulation of problems during several decades of the Pahlavi regime (1921-78), made the necessity of a system based on cooperation more and more tangible. The 1978 revolution was a reply to this need and a rise against tyranny. 


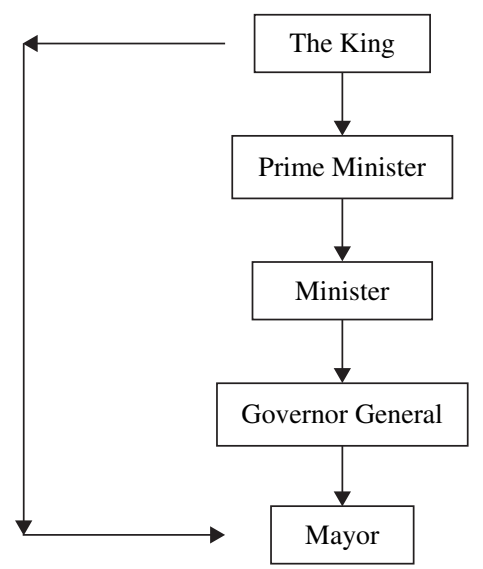

Figure 3: The structure of the urban management system before the revolution (1978).

\section{THE ISLAMIC REVOLUTION OF IRAN AND PARTNERSHIP IN URBAN MANAGEMENT}

After the victory of the Islamic Revolution of Iran in 1978, there came a new period in the formation of democracy and partnership approaches to national, local, and regional management. One of the goals of the revolution was to separate urban management from the government and increase the level of public partnership in the management of urban affairs. Thus decentralization, as opposed to centralization, which was emphasized by the previous regime, occupied an important position in the constitution and in the cultural, social, and economic development programs. The seventh principle of the constitution is quite explicit about Islamic councils (country councils or 'parliament', province councils, city councils, neighborhood councils) as main centers for making decisions and managing the country [18]. In 1982, the parliament passed the law of formation of Islamic councils in an attempt to boost the development programs. In spite of the fact that new laws were ratified in 1996 concerning the formation of city Islamic councils, city councils did not come into being until 1998, when city and village Islamic council elections were held. Before that, city management followed a traditional centralized method (Fig. 4).

In 1998, the first city Islamic council elections were held. This was a turning point in the revolution, as a result of which a new approach based on public partnership began to be experienced. This was the first step toward the division of power and transfer of authority to the lower ranks of the society, promising a fruitful future for urban management in Iran. The purpose was to modify people's expectations and demands and to institutionalize their presence in political, social, construction spheres, turning the people's political dissatisfaction into satisfaction and, ultimately, into national solidarity.

\section{CITY COUNCIL - THE LINK BETWEEN PEOPLE AND CITY MANAGEMENT}

As stated above, the formation of city councils in 1998, whose aim was to decentralize and speed up the enforcement of laws and provide people with more power in running their local affairs, was a perfectly new approach to urban management, especially in metropolises like Tehran, Mashhad, Tabriz, and Isfahan, after the Islamic revolution. Also, the formation of city Islamic councils (after 95 years), was a new approach to administrative democracy at a national level in Iran [19]. The purpose 


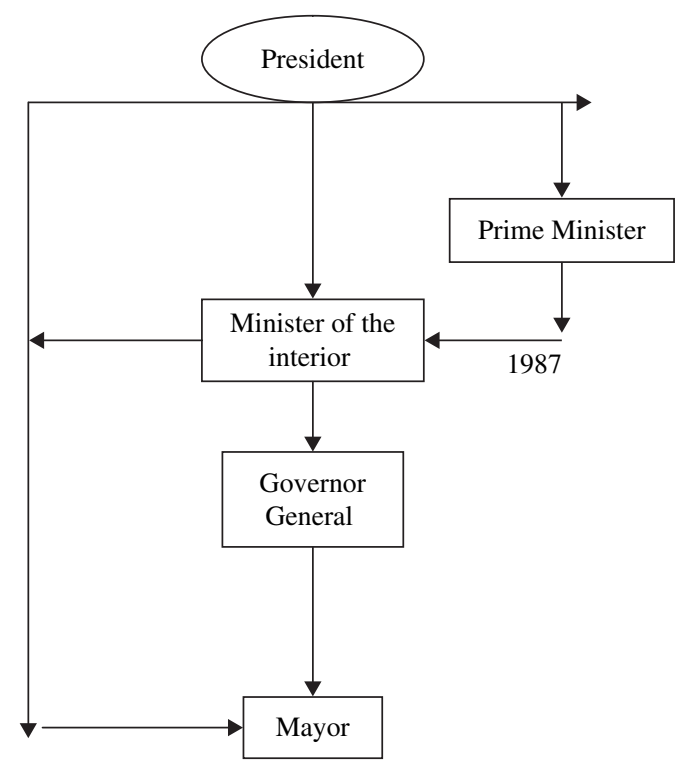

Figure 4: The structure of the urban management system before the year 1998.

of the approach is to, by establishing local governments, encourage people to participate directly in running their city affairs [20]. On the other hand, the link between citizens' economic-social interests and the function of city management is among the factors that keep city councils as bridges connecting people and city management.

After the formation of city Islamic councils, there was a fundamental change in city management toward streamlining public requests and developing social justice [21]. The city Islamic councils of the metropolises have been considerably successful in realizing these goals and in establishing a close link between city management and the people [22]. However, this trend has faced challenges in small cities (Fig. 5).

\section{MASHHAD AND ITS PROCESS OF TURNING INTO A METROPOLIS}

Mashhad, literally 'the place of martyrdom', came into being as a city in the year 785, when Imam Reza, the eighth Imam of the Shi' ite Muslims, was martyred and buried. During the last 50 years, social changes including a population growth at a rate of $8.7 \%$ during the years 1976-86, immigration from outside and inside the province, and religious factors have brought about vast changes in the city, turning it into the second largest metropolis in the country. On the other hand, the geopolitical situation of the city has had a great part in turning Mashhad into the mother city in the eastern side of the country: the Iran-Iraq war, which resulted in a mass immigration of people from the war-stricken areas to Mashhad; the occupation of Afghanistan by the Soviets in 1987, which resulted in the immigration of Afghans to Iran, 39\% of whom settled in Mashhad [23]. These two factors had a great effect on the qualitative and quantitative growth and development of the city. Mashhad is now the greatest Islamic city in Afghanistan, Central Asia, and China, a center for organizing cultural and religious activities in a region as large as 6.5 million square kilometers with a population over 65 million. At present, Mashhad is host to 12 million pilgrims each year and this makes it the world's second largest religious metropolis. 


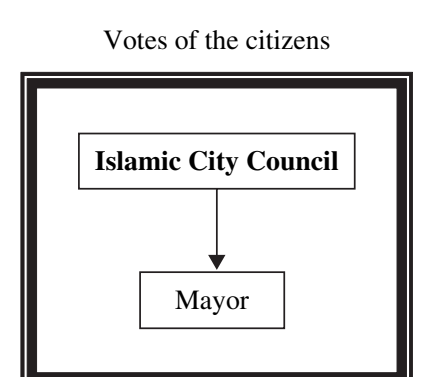

Figure 5: The structure of the urban management system after the year 1998.

\section{MASHHAD - AN EXAMPLE OF DICTATORIAL MANAGEMENT BEFORE THE REVOLUTION}

After the constitutional revolution and the ratification of the first law of municipalities, in certain cities municipalities were established with the purpose of maintaining cleanliness and hygiene. (The first municipality was established in Tehran in 1907.) Because of its religious significance and geographical location as the most important urbanized center in the east of Iran, Mashhad was among the cities that needed a municipality for organizing its city affairs. The Mashhad municipality was established in 1912. The mayor was appointed by the governor of the province and was considered the agent of the Shah and the government. The change in the political system from the constitutional system to the Pahlavi regime in 1921 and to the Islamic Revolution in 1978 brought about great social, political, and construction changes in Mashhad. The destruction of the walls around the old city of Mashhad, an increase in the rate of immigration from villages, the creation of growth regional poles in the development of urban space are some of the factors that have been influential in turning Mashhad into the regional mother city in the east of the country. During the Pahlavi regime (1921-78), urban management followed a centralized pattern.

According to the law, the minister of the interior, as the vice president of the city council, appointed the mayor, who was the agent of the government and enjoyed full authority. In the 1960s, the modernization strategy, which tended toward industrialization, affected great cities like Mashhad and developed the city which had to also face great new urban challenges. An increase in the rate of immigration, the number of poor people living in slums around the city, and poverty added to the problems of city management which was traditional and dictatorial and the need for a collective approach based on people's partnership became all the more evident.

\section{MASHHAD - URBAN MANAGEMENT AFTER THE 1978 REVOLUTION}

The failure of Land Reform Project in the 1960s resulted in more extensive migration from villages. After the revolution, there was an increasing growth in the population and challenges in urban management. The war between Iran and Iraq, the occupation of Afghanistan, population growth, and migration increased the regional power and significance of Mashhad and turned it into the second largest religious metropolis in 1986. The combined political, social, and economic factors and the geographical position of the city at national, regional, and international levels made the management of the city all the more complicated. Lack of a system of counseling in the urban management and the centralization of the management were the two most important factors contributing to the instability of urban management and its slowness in overcoming problems and challenges. This process continued until 1998. 


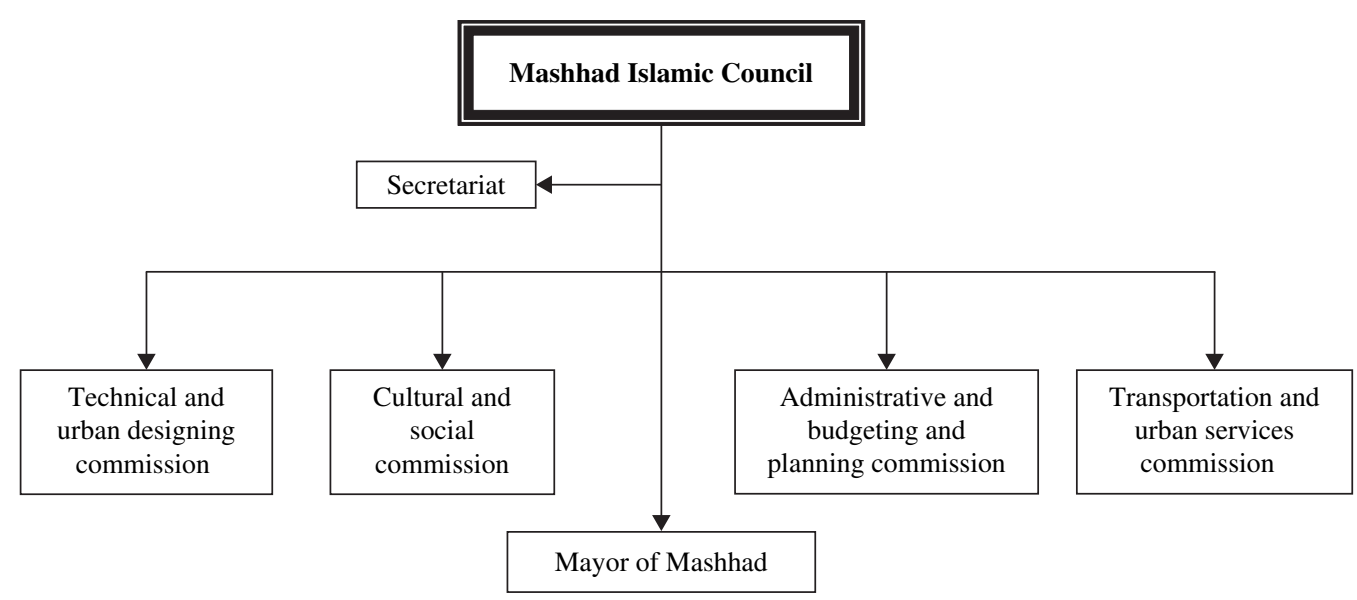

Figure 6: The structure of the urban management system of the Mashhad religious metropolis (1998-2002).

\section{THE RELIGIOUS METROPOLIS OF MASHHAD AND THE PARADIGM OF URBAN MANAGEMENT IMPROVEMENT}

The formation of the Islamic Council of the city of Mashhad in 1998 provided the municipality with an appropriate approach for improvement. Based on this approach, the metropolis would be managed by a council. According to the law, the citizens elect 11 people for a period of 4 years, who, as members of the city council, play an important role in the management of the city. At present, all the activities of the municipality are carried out based on the new partnership approach. First, a need analysis is carried out. Then the problems of the city are prioritized, which are discussed by the city council before decisions are made about them. The city council has various commissions that meet every week to discuss various problems (Fig. 6).

Thus, all the activities of the municipality are carried out with the agreement of the city council representing the people. The city council holds an open meeting once a week where people can air their views and see for themselves the way the council works. This strengthens the link between the people and the municipality. This management system presents an ideal management pattern for the religious metropolis of Mashhad and it is expected that this approach, which is still in its infancy, will prove successful in its aim of permanent development and the strengthening of public institutes in a metropolis that is host to 12 million pilgrims every year.

\section{CONCLUSION}

A brief survey of the urban management trend in Iran showed that until three years ago, the cooperative approach to the administration of public affairs, especially urban management, had not been established because the governments were centralized and dictatorial before the revolution and there were no appropriate conditions and means for its materialization after the revolution. Factors such as the increase in urbanization at the rate of $62 \%$, the merging of metropolises, and the complexity of the urban system necessitated the formation of Islamic city councils and the separation of city management from the government. After the formation of Islamic city councils, the new 
approach to urban management provided the ground for the management of councils, marking a new era of sharing city management with the people. The 95 -year-old history of city management in Iran shows that the centralized and dictatorial urban management has contributed greatly to the failures of projects and the dissatisfaction of the people, and that there have always been civil movements aspiring to partnership in running city affairs. The Islamic Revolution was a reply at a national level to this demand and the formation of Islamic councils was a reply to the necessity of management based on partnership. At present, the management system of council-mayor has been regarded as the most effective paradigm of city management in Iran. It is expected that in the 21 st century, this approach will become more democratic in its turning of the local organization into the local government and the observance of the principles of stable development and strengthening partnership in civil and public institutes in city management, especially in metropolises. This trend has already started in the Mashhad religious metropolis and the city council and will continue to flourish.

In the present circumstances, gloomy realities like the spread of poverty, pollution, erosion of the environment in metropolises and the emergence of mega-cities have hindered stable development, especially stable development in cities; running the cities using a method based on partnership with people and civil institutes and the optimal use of resources is unavoidable. On the other hand, the global trend of urbanization necessitates a comprehensive approach in the management of cities, management that must be based on efficiency, justice and partnership, and localization. Also, attention to popular institutions in running cities in the 21 st century and the union of metropolises in the form of regional cooperation can result in the improvement of life and can help in the change from the local organization to the local government. To achieve this end, urban planning must be promoted to regional planning and emphasis must be placed on regional development management. The new millennium, if ecological considerations are taken into account, should be hailed as the age of the dominance of popular institutions.

\section{REFERENCES}

[1] UNESCO, The Urban Jungle, available at http://www.unesco.org, 6 July 2001 (accessed 29 September 2001).

[2] Yarahmadi, A., Toward a Humanitarian Urbanization, Tehran Municipality's Office for Planning and Processing: Tehran, p. 199, 1999.

[3] Arjmandnia, A., Non-governmental organizations. Modiriyat Shahri Quarterly, 2(5), p. 29, 2001.

[4] Shakoori Moghaddam, M., The Role of Information Technology in the Development of the Organization of Municipalities, Zarreh Publishers: Tehran, p. 58, 2000.

[5] UNCHS, An Urbanizing World, OUP, p. 422, 1995.

[6] Nejati Hosseini, M., The new paradigm of urban management. Faslnameh Modiruyat Shahri, 1(1), p. 7, 2001.

[7] Pilehvar, A., Cooperation and spread of justice in the urban environment. Cooperation Monthly, No. 205, p. 50, April 2001.

[8] Yalda, T., Renovation of neighborhoods, an approach to attracting people's partnership. Shahr Quaterly, 1(3), p. 24, 1999.

[9] Shakiba Moghaddam, M., Management of Local Organizations and the Municipality, Hoor Publishers: Tehran, 1995.

[10] Saeed Nia, A., Urban Management, Organization for the Country's Municipalities: Tehran, 2001. 
[11] Alavitabar, A., A Survey of the Idea of Citizens' Partnership in Running Cities (Iran and World Experiences), Organization for the Country's Municipalities: Tehran, 2000.

[12] Pilehvar, A.A., Partnership approach, an issue in urban management. Modabber, 2(15), p. 2, 2001.

[13] Habibi, M., From Shar to Shahr, Tehran University Press: Tehran, p. 146, 1996.

[14] World Geographical Encyclopedia, 3, McGraw-Hill, Inc.: London, p. 36, 1995.

[15] Razzaghi, E., An Introduction to the Economy of Iran, 3rd print, Tehran, Nashr, p. 142, 2001.

[16] Momeni, M., Position of Geography in Iran, The Islamic Republic of Iran Academia of Sciences: Tehran, p. 33, 1998.

[17] Rasaeenia, N., The Constitution of the Islamic Republic of Iran, Saman Publishers: Tehran, p. 28, 1998.

[18] Mozayyeni, M., Urban and Rural Management in Iran, Ministry of Housing and Cities: Tehran, p. 53, 1996.

[19] Noroozi, K., An introduction to the basics of the rights of the Islamic councils. Shahrdaarihaa Monthly, Published by the State Organization for the Municipalities, 1(1), p. 32, 1999.

[20] Rahnama, M.R., The paradigm for the improvement of urban management. Geographical Research Quarterly, 16(61), Mashhad, p. 63, 2000.

[21] Zokaee, M., Councils, inexperienced in attracting partnership. Shahrdaarihaa Monthly, 2(20), p. 10, 2000.

[22] Papoli Yazdi, M.H., Political impacts of Afghan refugees in Khorassan. Geographical Quarterly, 4(15), Mashhad, p. 7, 1989.

[23] Papoli Yazdi, M.H., Geopolitical significance of the east of Iran. Geographical Quarterly, 12(44), Mashhad, p. 6, 1997. 